\title{
PEMEROLEHAN BAHASA AUD AUTIS PADA SEKOLAH EKSKLUSIF YANG INKLUSIF (STUDI DESKRIPTIF DI TALENTA KIDS SALATIGA)
}

\author{
Khoirul Bariyyah \\ UIN Sunan Kalijaga Yogyakarta \\ Email: khoirul.bariyyah29@gmail.com
}

\begin{abstract}
This study aimed to know language acqiusition of early childhood students with special need especially with autism. The subject of this study is students with autism in Sekolah Autis Talenta Kids Salatiga. This study use qualitative approach. The data is collected by interview, direct observation and documentation study. The data analyzed in four steps that are data collection, data reduction, data display, and conclussion drawing. The researcher use triangulation of techniques to check data validation. The result shows that Talenta Kids is exlusive school that conducted the principal of inclusive school. Language acquisition of students with autism in Sekolah Autis Talenta Kids is conducted trough five steps. That steps are: 1) identification of students with autism's needs, 2) speech teraphy by paraprofessional collaborate with the teacher and parents, 3) message teraphy, 4) peer interaction, 5) interaction with school environment.
\end{abstract}

Keywords: Language Acquisition, Autistic Early Childhood

\begin{abstract}
Abstrak
Penelitian ini bertujuan untuk mengetahui pemerolehan bahasa pada anak usia dini berkebutuhan khusus dan difokuskan pada anak usia dini penyandang autis. Subjek kajian dalam penelitian ini adalah anak usia dini penyandang autis di Sekolah Autis Talenta Kids Salatiga. Penelitian ini menggunakan pendekatan kualitatif dengan metode deskriptif. Data diperoleh melalui wawancara, observasi langsung dan studi dokumentasi. Analisis data kualitataif melalui empat alur yaitu pengumpulan data, reduksi data, display data, dan penarikan kesimpulan. Peneliti menggunakan triangulasi teknik untuk menguji validitas data hasil penelitian. Hasil penelitian menunjukkan bahwa pemerolehan bahasa di Sekolah Autis Talenta Kids dilakukan melalui lima tahapan. Tahapan tersebut antara lain: 1) identifikasi kelainan pada anak autis, 2) terapi wicara yang dilakukan oleh para profesional bekerjasama dengan guru dan orang tua, 3) terapi message, 4) interaksi dengan teman sebaya, 5) interaksi dengan lingkungan sekitar sekolah.
\end{abstract}

Kata Kunci: Pemerolehan Bahasa, AUD Autis 


\section{PENDAHULUAN}

Bahasa memiliki peranan yang penting bagi setiap manusia, karena bahasa merupakan alat komunikasi primer dalam kehidupan sehari-hari. Tanpa bahasa, manusia tidak dapat menyampaikan informasi, gagasan, pikiran, dan kemauannya pada orang lain secara lengkap. Dengan demikian, jelaslah bahwa bahasa mempunyai peran penting dalam kehidupan untuk meningkatkan kemampuan dan motivasi anak dalam pembelajaran, baik pembelajaran yang bersifat formal maupun non formal (Ezmar dan Ramli, 2014: 2).

Kemampuan daya pikir anak dapat ditentukan oleh kemampuan berbahasanya. Jika pemahaman berbahasa tinggi, maka daya pikir anak pun luas. Untuk memperoleh daya pikir yang baik, setiap anak harus dibekali dengan tata bahasa dan dilatih kemampuan berbahasanya. Begitu juga untuk menyampaikan maksud kepada guru atau teman sebaya, seorang anak harus mengguanakan bahasa yang baik dan benar, baik lisan maupun tulisan. Jika anak menggunakan bahasa yang baik dan benar maka penerima informasi (pendengar) akan cepat dan mudah meresponnya. Sebalikanya, jika bahasa yang digunakan kurang tepat maka informasi akan putus dan keinginan yang dimaksud tidak akan tersampaikan. Begitu lah yang sering terjadi pada anak penyandang autis (Ezmar dan Ramli, 2014: 2).

Autis adalah suatu kelainan neurologis (neurological disorder) yang seringkali mengakibatkan ketidakmampuan komunikasi dan interaksi sosial. Autis tiga kali lebih sering terjadi pada anak laki-laki daripada anak perempuan. Meskipun autis dianggap sebagai kelaian psikologis, penyebab pastinya belum diketahui dalam beberapa kasus (Smith, 2013: 150).

Ketrampilan berbahasa sangat beragam di spektrum autis. Beberapa anak penyandang autis tidak suka berbicara. Namun, yang lain memiliki kemampuan luar biasa mengeja kata hanya dari sekali mendengar, atau mengajari diri sendiri membaca di usia dua atau tiga tahunan, atau mengembangkan kosakata yang sudah mirip orang dewasa padahal masih di SD, atau berbicara dengan sangat detail dan panjang lebar tentang topik-topik yang menarik minat mereka (Sastry dan Aguirre, 2014: 205-206). Sementara itu hasil peneitian Braten Ellen dan Felopulus menunjukkan bahwa 2/3 sampai 50\% anak penyandang autis tidak mengalami perkembangan bahasa dan tidak dapat berkomunikasi dengan baik. Kemampuan berbahasa anak yang memiliki gejala autis dapat dilihat sejak usia 14 bulan, namun memiliki gejala yang tetap pada usia 2 sampai 3 tahun. Pada saat itu anak autis jarang mengeluarkan suara yang bermakna, seperti yang sering dilakukan anak normal, bahkan ada anak yang cenderung membisu tidak mau bersuara. Namun ditemukan kecenderungan anak autis yang mengulangi kembali apa yang diucapkan oleh orang lain (Ellen dan Gretchen, 2004).

Kebanyakan anak penyandang autis mengalami kesulitan menggunakan bahasa secara efektif, khususnya di dalam interaksi sosial. Banyak yang berbicara menggunakan ritme dan nada yang tidak lazim, atau terlalu formal penggunaan kalimatnya. Sudah lazim bagi anak penyandang autis mengalami kesulitan di dalam membedakan makna bahasa lisan dan tertulis, bahasa tubuh, nada suara dan intonasi, dan terus bergumul untuk bisa merespon dengan tepat (Ezmar dan Ramli, 2014: 206). Tidak jarang pula penyandang autis tantrum karena keinginannya juga tidak dapat dipahami oleh orang lain. Maka dari itu kemampuan berbahasa yang baik pada anak autis perlu diupayakan dan disesuaikan dengan karakteristik masing-masing anak penyandang autis itu sendiri.

Kemampaun berbahasa itu dapat diperoleh melalui pendidikan baik dari sekolah inklusif ataupun sekolah eksklusif. Individuals with Disabilities Education Act (IDEA) menegaskan bahwa negara bagian menjamin kelas-kelas khusus, sekolah terpisah, atau bentuk-bentuk lain pemisahan siswa yang berkelainan-boleh dilakukan/terjadi hanya- bila pendidikan anak-anak ini menggunakan alat-alat bantu tambahan dan layanan pembelajaran 
tidak mendapatkan kemajuan yang berarti di kelas-kelas regular (Smith, 2013: 41). Alasan ini juga yang menyebabkan kebanyakan orang tua yang memiliki anak autis di Salatiga lebih memilih untuk menyekolahkan anaknya di Sekolah Autis Talenta Kids daripada di sekolah inklusi.

“...dulunya RJ bersekolah di Sekolah Inklusi di kota B mbak, tapi saya lihat kemampuan berbahasanya tidak berkembang, makanya saya memilih sekolah ini -Talenta Kids- sekarang." 1

Berdasarkan latar belakang di atas maka peneliti merasa perlu untuk mengungkap metode pemerolehan bahasa yang diberikan di Sekolah Autis Talenta Kids, sehingga anak yang tadinya mengalami gangguan berbicara, dapat berbicara dengan baik dan lancar. Selanjutnya, peneliti berharap metode tersebut dapat diadopsi dan diterapkan oleh sekolahsekolah inklusif yang lain, dengan harapan dapat membantu perkembangan pemerolehan bahasa khususnya pada anak usia dini penyandang autis.

\section{METODE PENELITIAN}

Penelitian ini merupakan penelitian lapangan dengan menggunakan pendekatan kualitatif deskriptif. Penelitian dilakuakn di Sekolah Autis Talenta Kids Tegalrejo Kota Salatiga. Proses pengumpulan data menggunakan teknik observasi partisipatif (participat observation) dan wawancara mendalam (indepth interview). Peneliti menggunakan teknik purposive sampling untuk menentukan sumber data dalam penelitian ini. Purposive sampling merupakan teknik pengambilan sumber data dengan pertimbangan tertentu. Misalnya, orang yang dainggap paling tahu dan dapat memberikan informasi yang diharapkan, atau seorang penguasa yang dapat memudahkan peneliti untuk menjelajahi objek/ situasi sosial yang diteliti (Sugiyono, 2010: 305). Sample dalam penelitian ini adalah dua siswa autis yang bersekolah di Sekolah Autis Talenta Kids Salatiga. Untuk menjaga nama baik anak, peneliti menggunakan inisial RJ dan RV.

Sumber data yang digunakan dalam penelitian ini adalah sumber data primer dan sekunder. Sumber data primer merupakan sumber data yang diperoleh dari lapangan (Moleong, 2012: 217). Adapun sumber data primer dalam penelitian ini adalah Kepala Sekolah Autis Talenta Kids Tegalrejo Kota Salatiga dan salah satu guru kelas Sekolah Autis Talenta Kids Tegalrejo Kota Salatiga. Mengingat penelitian ini adalah penelitian dengan pendekatan kualitatif, maka instrumen utama dalam penelitian ini adalah peneliti sendiri, peneliti yang datang sendiri ke lokasi, melakukan observasi, memilih informan dan melakukan wawancara dengan informan. Sementara sumber data sekunder, ialah data-data yang didapat dari sumber bacaan dan berbagai sumber lain seperti catatan harian, surat-surat resmi, atau surat pribadi ((Moleong, 2012: 217). Peneliti melakukan studi dokumentasi dan kepustakaan untuk memperoleh teori-teori dan konsep yang berhubungan dengan masalah yang dikaji dalam penelitian ini yakni pemerolehan bahasa anak autis atau autistic language Acquisition Data yang ditemukan kemudian dianalisis menggunakan teknik analisis data model Miles dan Huberman yang meliputi; data reduction, data display dan conclusion drawing (Emzir, 2011: 129). Peneliti juga menggunakan triangulasi teknik untuk menguji validitas data hasil penelitian. Triangulasi digunakan semata-mata untuk mencari kebenaran tentang berbagai fenomena (Sugiono, 2015: 328). Pada penelitian ini, peneliti menggunan triangulasi teknik dimana peneliti mencocokkan hasil pengamtan, wawancara dengan nara sumber dan hasil studi dokumentasi untuk memperoleh data hasil penelitian yang teruji kevalidannya.

\footnotetext{
${ }^{1}$ Hasil wawancara dengan nenek R, salah satu siswa autis yang sembuh dari gagap di Talenta Kids yang dilakukan peneliti pada tahap penelitian pendahuluan (pra-research).
} 


\section{HASIL DAN PEMBAHASAN}

\section{Talenta Kids: Sekolah Eksklusif yang Inklusif}

Talenta Kids adalah satu-satunya sekolah autis di Kota Salatiga. Talenta Kids didirikan untuk menjawab akan perlunya pendidikan untuk anak yang mengalami gangguan perkembangan dan autis. Talenta Kids memberikan pelayanan dan penanganan sejak dini bagi anak autis yang mengalami hambatan dalam berkomunikasi, bersosialisasi, sensorik, perilaku, dan emosi. Selain itu Talenta Kids juga didirikan untuk memberikan layanan pendidikan yang sesuai dengan kebutuhan setiap anak (Arsip Talenta Kids Salatiga).

Sekolah ini beralamatkan di Perum Griya Mustika No. 2 RT 07 RW 04 Jalan Gondangsari, Tegalrejo, Kecamatan Sidomukti, Kota Salatiga. Sekolah ini berada di bawah naungan Kanz Kids Family Foundation. Talenta Kids didirikan pada tanggal 1 Mei 2008. Saat itu sekolah belum memiliki nama begitu juga yayasan yang menaunginya. Nama Talenta Kids baru digunakan di akhir tahun 2008. Sementara yayasan Kanz Kids Family juga baru didirikan pada tahun 2009. Awalnya kegiatan pembelajaran dilaksanakan di rumah Kepala Sekolah Autis Talenta Kids, yakni Dr. Hj. Lilik Sriyanti, M.Si sebelum bangunan permanen sekolah didirikan pada tahun 2010 (Arsip Talenta Kids Salatiga).

Walaupun sekolah ini merupakan sekolah yang eksklusif, namun fasilitas yang diberikan dan metode yang digunakan menjadikan sekolah ini seperti sekolah inklusif. Lingkungan sekolah benar-benar didesain untuk memenuhi kebutuhan setiap anak, meja kursi yang digunakan ramah anak, semua fasilitas di sana dapat dengan mudah dijangkau oleh anak. Sekali waktu anak diberi kesempatan untuk melihat video atau menonton TV agar mengetahui isu yang sedang berkembang. Ketika waktu istirahat anak dapat berinteraksi dengan teman-temannya di lingkungan Sekolah. Kesan eksklusif juga menjadi luntur karena anak sering diajak untuk berinteraksi dengan masyarakat sekitar perumahan. Anak juga diberikan waktu untuk jalan-jalan dan menikmati keindahan lingkungan sekitar sekolah setiap hari Jumat dengan didampingi oleh seluruh guru.

Mohammad Takdir Ilahi mengungkapan bahwa sekolah inklusi menggunakan kurikulum nasional yang dimodifikasi sedemikian rupa untuk memenuhi kebutuhan ABK (Ilahi, 2013: 172). Dilihat dari kurikulumnya, Talenta Kids menggunakan kurikulum nasional sama seperti yang diajarkan di sekolah umum, namun demikian tetap dimodifikasi dan disesuaikan dengan kebutuhan masing-masing anak. Kepala sekolah sangat menghargai kebutuhan masing-masing anak yang berbeda, sehingga sekolah ini menawarkan sistem pembelajaran one-to-one aide yang berarti bahwa satu anak ditangani oleh satu guru. Ibu Vina, salah seorang guru di Talenta Kids mengatakan,

“... Karena setiap anak mempunyai kelemahan yang berbeda, maka dibimbing satu anak satu guru... kurikulum yang dipakai itu ombinasi anatara kurikukum umum yang disesuaikan dengan kebutuhan anak. " (Vina, Wawancara: 18 November 2016)

Menurut Robertson, Camberlin, \& Kasari, di America one-to-one aide diterapkan di sekolah dengan setting sekolah inklusif. One-to-one aide, dilakukan oleh paraprofesional dan diterapkan tidak hanya bagi anak autis saja tetapi juga anak dengan disabilitas yang lain (Robertson dkk, 2003: 123). Maka dari itu, peneliti berasumsi bahwa sekolah ini sebenarnya merupakan sekolah eksklusif yang di-setting seperti sekolah inklusi.

Ada beberapa program khusus yang ditawarkan di sekolah ini. Program khusus tersebut antara lain; program pembelajaran individual, terapi visual, terapi perilaku, sensory integrasi, terapi musik, terapi massage, terapi wicara, dan terapi bermain. Beberapa progam ini diberikan kepada anak sesuai dengan hasil diagnosis pada masing-masing anak. Diagnosis ditentukan berdasarkan hasil pengamatan pada anak ketika anak mulai masuk Talenta Kids. Terkadang guru juga mendapatkan informasi tentang kebutuhan anak 
berdasarkan catatan hasil diagnosis dokter yang dibawa oleh orang tua saat mendaftarkan anaknya.

Pada tahun 2016 ada 21 anak penyandang autis yang bersekolah di Talenta Kids, empat diantaranya pernah mengalami gangguan berbicara/komunikasi. Saat ini, dua anak autis yakni Hilbran dan Avi yang masih berusia 4-5 tahun masih mengalami keterlambatan bicara, dan masih dalam masa terapi. Sementara dua anak lainnya, bernama RJ dan RV yang berusia sembilan tahun sudah dapat berbicara dan berkomunikasi dengan baik, namun cenderung hiperactive dan "cerewet". Awalnya ketika masuk ke sekolah tersebut RV mengalami keterlambatan bicara. Begitu juga dengan RJ, awalnya RJ juga mengalami gangguan bicara gagap. Hal ini sebagaimana diungkapkan oleh Nenek RJ yang tinggal tidak jauh dari lingkungan sekolah.

"Wah mbak, sekarang dia itu tidak mau berhenti bicara, semua ditanyakan. Saya juga tidak tahu, kadang sampai kuwalahan menjawab pertanyaannya. Mungkin karena dulu dia tidak bisa berbicara lancar, jadi sekarang setelah bisa berbicara dia jadi banyak bicara. (Nenek RJ, Wawancara, 18 November 2016) "

Pernyataan ini sesuai dengan pernyataan Ibu Lilik Sriyanti, Kepala Sekolah Autis Talenta Kids Salatiga.

“...Raja itu bukan tidak dapat berbicara sebenernya, tetapi dia mengalami gangguan berbicara. Gagap. Sekarang sudah lancar kan bicaranya?” (Lilik Sriyanti, wawancara: 21 November 2016).

\section{Pemerolehan Bahasa Anak Autis di Talenta Kids}

Pemerolehan bahasa (language acquisition) atau akuisisi bahasa menurut Maskan adalah suatu proses penguasaan bahasa yang dilakukan oleh seseorang secara tidak sadar, implisit, dan informal. Sementara itu, Stork dan Widdowson mengungkapkan bahwa pemerolehan bahasa adalah suatu proses anak-anak mencapai kelancaran dalam bahasa ibunya. Kelancaran bahasa anak dapat diketahui dari perkembangan bahasanya, oleh karena itu akuisisi bahasa perkembangan dan penguasaan bahasa anak diperoleh dari lingkungannya dan bukan karena sengaja mempelajarinya. Bahasa anak berkembang karena lingkungan. Sedangkan Huda (dalam Suhartono, 2005: 70) menyatakan bahwa pemerolehan bahasa adalah proses alami di dalam diri seseorang menguasai bahasa. Pemerolehan bahasa biasanya diperoleh dari kontak verbal dengan penutur asli di lingkungan. Dengan demikian, istilah pemerolehan bahasa mengacu pada penguasaan bahasa secara tidak disadari dan tidak terpengaruh oleh pengajaran bahasa tentang sistem kaidah dalam bahasa yang dipelajari.

Pemerolehan bahasa (language acquisition) berbeda dengan pembelajaran bahasa (language learning). Pemerolehan bahasa adalah proses yang berlangsung didalam otak anak-anak ketika dia memperoleh bahasa pertamanya atau bahasa ibunya (Chaer, 2009: 167). Dalam bahasa Inggris pemerolehan bahasa ini sering disebut dengan istilah language acquisition. Bahasa yang diperoleh dapat berupa bahasa lisan ataupun bahasa isyarat. Bahasa ini diperoleh secara natural tanpa kesengajaan untuk mempelajarinya. Sementara pembelajaran bahasa berkaitan dengan proses-proses yang terjadi pada waktu seorang kanak-kanak mempelajari bahasa kedua setelah dia memperoleh bahasa pertamanya. Jadi, pemerolehan bahasa berkenaan dengan bahasa pertama, sedangkan pembelajaran bahasa berkenaan dengna bahasa kedua. Pembelajaran bahasa ini terjadi secara sadar dan disengaja (Syukron dan Nisa, 2014:-).

Berdasarkan hasil penelitian empiris, terdapat dua teori utama tentang bagaimana manusia memperoleh bahasa pertamanya, yakni Nativist Theory dan Learning Theory. Nativist theory adalah teori yang menyebutkan bahwa manusia memperoleh bahasa secara alami. Teori ini kemudian dikenal dengan hipotesis nurani yang dipelopori oleh Leneberg dan Noam Chomsky. Teori ini menegaskan bahwa bahasa merupakan warisan, manusia 
sejak lahir sudah dibekali genetik untuk berbahasa. Maka hipotesis naluri berbahasa merupakan suatu asumsi yang menyatakan bahwa sebagian atau semua bagian bahasa tidaklah diperoleh atau dipelajari, akan tetapi ditentukan oleh fitur-fitur nurani yang khusus dari organisme manusia. Sementara learning theory adalah teori yang menyatakan bahwa pemerolehan bahasa melalui proses mempelajari. Sebagai penjelasan dari teori ini adalah bagaimana seorang bayi mulai berbahasa. Pada tahapan ketika anak memperoleh sistemsistem bunyi bahasa ibunya, semula dia mengucapkan sistem bunyi yang ada di semua bahasa di dunia ini. Namun, karena lingkungan telah memberikan contoh terus-menerus terhadap sistem bunyi yang ada pada bahasa ibunya, dan dimotivasi terus untuk menirukan sistem bahasa ibunya, maka akhirnya yang dikuasai adalah sistem bahasa ibunya (Chaer, 2009: 168).

Anak yang mengalami gejala autis seringkali memiliki masalah dengan kemampuan berbahasanya. Bahkan 2/3 sampai 50\% anak penderita autis, tidak mengalami perkembangan bahasa dan tidak dapat berkomunikasi dengan baik. Kemampuan berbahasa anak yang memiliki gejala autis dapat dilihat sejak usia 14 bulan, namun memiliki gejala yang tetap sejak usia 2 sampai 3 tahun. Pada saat itu, anak autis jarang mengeluarkan suara yang bermakna, seperti yang sering dilakukan anak normal, bahkan ada anak yang cenderung membisu tidak mau bersuara. Namun ditemukan kecenderungan anak autis yang selalu mengulangi kembali apa yang diucapkan orang lain (Ellen dan Gretchen, 2014: -).

Kemampuan penguasaan bahasa pada anak autis, perlu diajarkan dengan sabar oleh seorang terapis (seseorang yang sudah mengikuti pelatihan untuk menangani anak autis), karena kemampuan berbahasa anak autis tidak dapat tumbuh dengan sendirinya. Kemampuan berbahasanya akan bertambah baik, sejalan dengan usaha maksimal dari orang lain yang berada di lingkungan terdekatnya (Ezmar dan Ramli, 2014: 9).

Keberhasilan Talenta Kids dalam meningkatkan kemampuan pemerolehan bahasa anak autis di Talenta Kids sudah diakui oleh banyak pihak. Keberhasilan Talenta Kids dalam meningkatkan kemampuan berbahasa anak juga tidak diragukan lagi. Banyak orang tua yang lebih memilih menyekolahkan anaknya di Talenta Kids daripada di PAUD inklusi di Salatiga atau sekolah inklusi yang lain. Hal ini karena Talenta Kids memiliki beberapa keunggulan dalam hal penanganan kebutuhan anak dibandingkan dengan PAUD inklusi di sekitar Kota Salatiga. Talenta Kids menyerahkan penanganan terkait pemenuhan kebutuhan anak kepada tenaga ahli, seperti ahli terapi wicara, terapi message sementara di PAUD inklusi tidak. Bahkan terkadang PAUD inklusi belum memiliki tenaga ahli. Ketika anak didiagnosis mengalami keterlambatan bicara (speech delay) maka anak akan langsung ditangani oleh seorang terapis bicara. Penanganan di sekolah ini pun secara individual bukan klasikal seperti pada sekolah inklusi. Selain itu, guru di Talenta Kids sangat menyadari bahwa perkembangan bahasa anak terjadi pada rentang usia tertentu, sehingga pihak Talenta Kids selalu berupaya memberikan terapi sedini mungkin. Hal ini sesuai dengan pernyataan Ibu Lilik,

"Mereka (orang tua) lebih memilih untuk menyekolahkan anaknya di sini, daripada di PAUD inklusi karena pada umumnya PAUD inklusi di Salatiga belum mempunyai tenaga ahli, penanganannya masih klasikal, dan tidak menyadari bahwa perkembangan bahasa itu terjadi pada rentang waktu tertentu saja, sehingga mereka (PAUD inklusi) tidak melakukan terapi sedini mungkin." (Lilik Sriyanti, Wawancara: 21 November 2016).

Berdasarkan hasil penelitian tersebut, terlihat bahwa Talenta Kids lebih menggunakan prinsip learning theory bukan Nativist Theory. Pemerolehan bahasa ibu bagi anak autis di Talenta Kids tidak bias terjadi secara alamiah saja, tetapi harus melalui proses pengajaran atau pemberian contoh-contoh bunyi dari orang-orang yang tinggal di lingkungan sekitar anak atuis itu sendiri seperti teman, guru, orang tua dan masyarakat di lingkungan tempat tinggal anak. Selain pemberian contoh, Talenta kids juga menerapkan 
berbagai terapi untuk membantu mempercepat proses pemerolehan bahasa bagi peserta didiknya.

Talenta Kids menerapkan beberapa metode untuk meningkatkan pemerolehan bahasa pada anak dan fungsionalisasi bahasa yang diperoleh tersebut. Setidaknya terdapat 5 tahapan yang dilalui anak dengan keterlambatan berbicara atau mengalami gangguan bicara. Kelima tahapan tersebut antara lain sebagai berikut:

Tahap Pertama Indentifikasi Kebutuhan Anak. Setiap anak yang autis memiliki karakteristik kebutuhan yang berbeda-beda, sehingga tidak mungkin untuk disamakan dengan yang lainnya. Guru harus mengetahui jenis kebutuhan anak dan mengetahui metode pembelajaran yang tepat bagi anak tersebut agar tujuan pembelajaran dapat tercapai. Setiap anak mungkin memiliki kurikulum yang berbeda sesuai dengan tujuan pembelajarannya. Tujuan pembelajaran dalam PPI berbeda dengan tujuan pembelajaran pada umumnya. Ibu Vina salah satu guru di Talenta Kids mengatakan bahwa;

"karena setiap anak mempunyai kelemahan yang berbeda, maka dibimbing satu anak satu guru. Setiap anak punya kurikulum dan jadwal sendiri-sendiri. Ketika masuk, merkea ada diagnosa jadi tahu kurikulum dan metode pembelajaran yang tepat untuk anak tersebut..."(Vina, Wawancara: 18 November 2016)

Senada dengan hal tersebut, Ibu Umi juga mengatakan bahwa mereka mengamati setiap siswa baru selama beberapa hari atau bahkan beberapa minggu untuk melihat sikap anak terlebih dahulu, menuliskan perilaku yang dianggap 'aneh' dan melakukan wawancara dengan orang tua juga. Jika ada perilaku yang menyimpang maka perilaku tersebut harus dihilangkan terlebih dahulu.

Berkaitan dengan pemerolehan bahasa, guru juga melakukan identifikasi terlebih dahulu. Biasanya guru melakukan identifikasi berdasarkan pada catatan rekam medis anak. Catatan tersebut bersumber dari terapis sang anak. Hal ini sesuai dengan pernyataan Ibu Lilik berikut:

"Begitu juga dengan layanan yang diberikan kepada anak autis yang mengalami gangguan bicara, kami menanganinya berdasarkan pada hasil assessment dokter, hasil pengamatan guru dan kategorisasi" (Lilik Sriyanti, Wawancara: 21 November 2016).

Sementara itu guru yang lain juga mengungkapkan hal yang sama. Mereka menggunakan metode yang berbeda untuk meningkatkan kemampuan beromunikasi anak, berdasarkan pada kondisi dari anak itu sendiri. Ibu Raras mengatakan,

"Kalau komunikasi biasanya kita sesuaikan dengan keadaanya. Kelamahannya apa. Ada anak yang bisa berbicara tapi bukan untuk berkomunikasi. Terapi di sini kan beragam mbak. (Raras, Wawancara: 21 November 2016).

Tahapan klasifikasi anak yang dilakukan oleh Talenta Kids sesuai dengan prinsip yang dikemukakan oleh Handojo. Walaupun Talenta Kids didirikan khusus untuk penyandang autis, namun pada kenyataannya autis tidak sesederhana namanya. Autis adalah gangguan yang berat terutama ditandai dengan gangguan pada area perkembangan seperti: keterampilan interaksi sosial yang resiprokal, keterampilan komunikasi, dan adanya tingkah laku yang stereotip, serta minat dan aktivitas yang terbatas. Sedangkan pengertian anak autis adalah kondisi anak yang mengalami gangguan perkembangan fungsi otak yang mencakup bidang sosial dan afeksi, komunikasi verbal dan non verbal, imajinasi, fleksibilitas, minat, kognisi, dan atensi (Pamuji, 2007: 2). Bahkan menurut Handojo, anak autis dapat diklasifikasikan menjadi empat kategori. Pertama, Autisma infantil yakni autisme pada masa kanak-kanak yakni terjadinya perkembangan otak anak sangat lambat. Kedua, Sindroma asperger yang mirip dengan autisma infantil, tetapi masih mau berkomunikasi dengan cukup baik hanya saja sering menunjukkan perilaku yang tidak wajar. Ketiga, Attention Deficit Hiperactive Disorder (ADHD) yakni gangguan pemusatan perhatian dan hiperaktivitas atau perilaku motorik yang berlebihan. Keempat, anak gifted adalah anak dengan intelegensi yang 
mirip dengan intelegensi super/ genius namun mereka sering memiliki perilaku yang aneh (Handojo, 2008: 12).

National Information Centre for Children and Young with Disablities (dalam Smith) menyatakan anak-anak dengan autism sering kali menunjukkan sifat-sifat kelainan yang dimulai sejak masa bayi, beberapa sifat-sifat tersebut antara lain; tidak tanggap terhadap orang lain; gerakan diulang-ulang seperti bergoyang, berputar, dan memilin tangan; menghindari kontak mata dengan orang lain; tetap dalam kebiasaan; memiliki sifat-sifat yang aneh dan ritualitas (Smith, 2013: 150).

\section{Tahap Kedua Terapi Bicara.}

Salah satu peran tak ternilai dari terapis bicara adalah memprioritaskan, merancang, dan memberikan terapi yang memenuhi kebutuhan paling kritis dan kebutuhan komunikasi sosial anak, memahami batasan-batasan spesifik keluarga sang anak, dan apa yang penting untuk orang tua sang anak. Para terapis wicara bertujuan untuk membuat anak autis mampu: berinisiatif melalui komunikasi spontan di aktivitas-aktivitas yang berguna dan fungsional, dengan rekan sosial siapa pun dan setting sosial apapun; memahami komunikasi verbal maupun non verbal di setting sosial, akademik maupun komunitas; berkomunikasi timbal balik untuk membantu berkembangnya persahabatan dan jaringan-jaringan sosial; menggunakan dan memahami cara-cara verbal maupun non verbal dalam komunikasi seperti gestur dan ekspresi wajah, ujaran atau perkataan, tanda-tanda atau petunjuk, gambargambar, dan kata-kata tertulis atau tulisan; mengakses kemelek-hurufan dan instruksi akademis, dan aktivitas-aktivitas kurikulum, ekstra kurikulum dan pekerjaan (Sastry dan Aguirre, 2014: 207-208).

Terapi bicara di Talenta Kids dilakukan oleh seorang terapis wicara bernama Nanang Hermawan. Dia adalah seorang ahli terapi bicara yang biasanya juga melakukan terapi bagi penderita stroke di Salatiga. Nanang hadir ke sekolah seminggu dua kali, sehingga keberhasilan terapi bicara tidak hanya ditentukan oleh seorang terapis melainkan juga guru yang menangani anak. J. Davd Smith mengungkapkan, selain terapis bicara, guru juga memiliki peranan yang tidak kalah penting dalam pemerolehan bahasa pada anak autis. Untuk menciptakan suatu lingkungan kelas yang inklusif, aturan pertama bagi guru untuk membantu anak dengan kelainan bahasa dan bicara adalah menciptkan suatu lingkungan yang mnedorong usaha-usaha komunikasi bersama pada semua siswa (Smith, 2013: 214). Hampir semua guru di Talenta Kids menguasai terapi bicara. Hal ini turut menjadi faktor pendukung utama keberhasilan Talenta Kids dalam mengembangkan pemerolehan bahasa anak usia dini penyandang autis yang bersekolah di sana.

"Hampir semua guru di Talenta Kids ini, menguasai terapi bicara. Jadi apa yang diajarkan oleh Nanang itu, juga diajarkan kepada guru sehingga guru dapat melakukan terapi bicara ketika Nanang tidak ada. Selain itu, Nanang memang menguasai ilmu terapi bicara, tetapi dia kan tidak mengauasai ilmu pendidikan anak. Bagaimana cara menguasai anak, bagaimana membujuk anak, karena dia biasanya melakukan terapi untuk penderita stroke."(Lilik Sriyanti, wawancara: 21 November 2016).

Berdasarkan hasil pengamatan, Guru di Talenta Kids membantu dan mendukung perkembangan positif kemampuan berbicara dan berbahasa anak dengan beberapa cara antara lain; memberikan contok berbicara yang baik melalui diri sendiri dengan berbicara jelas dan bersemangat; mendengarkan dengan kepekaan dan minat pada apa yang dikatakan anak; mengajarkan bahaa yang baik dan benar lebih banak melalui contoh-contoh daripada koreksi (misalnya ketika anak mengatakan, "Saya boleh nilai delapan", guru mengatakan, "Bagus, kamu mendapat nilai delapan."; menciptkan suasana ruang kelas yang membuat anak merasa nyaman untuk bertanya atau berpartisipasi dalam kelas; memeberikan penghargaan terhadap usaha anak untuk berbicara kepada guru atau teman yang lan; dan 
memberikan waktu yang cukup kepada anak untuk memformulasikan jawaban atas pertanyaan yang diajukan, sehingga siswa tidak merasa terburu-buru.

Terapis bicara menggarap berbagai aspek berbahasa: bahasa reseptif, atau memahami apa yang orang lain komunikasikan kepada sang anak; bahasa ekspresif, atau mengungkapkan kepada orang lain apa yang dimaksud oleh anak; pragmatika yaitu aspekaspek praktis dan sosial dari bahasa. Pragmatika meliputi berbagai aturan dan harapan sosial tentang bagaimana bahasa digunakan, seiring strategi-strategi untuk mengubah penggunaan bahaa di situasi yang berbda, khususnya yang kritis atau membahayakan. Semantika, yang berkaitan dengan makna dan penggunaan kata, frasa, dan kalimat (Sastry dan Aguirre, 2013: 209-210). Begitu juga yang terjadi di Talenta Kids, walaupun sebagian menggunakan istilah yang berbeda. Bahasa reseptif dan ekspresif diajarakan pada tahap terapi bicara, sementara pragmatik dan semantik diajarkan bersamaan dengan interaksi dengan teman dan masyarakat sekitar sekolah. Ada tiga tahapan yang dilakukan dalam terapi bicara, yakni kontak mata, instruksi, vocal. Ketika anak telah menguasai kontak mata dan instruksi berarti anak sudah dapat menguasai bahasa reseptif. Kontak mata merupakan ketrampilan dasar yang harus dikuasai anak sebelum terapi yang lain diberikan. Ketika anak belum mempunyai kontak mata, maka instruksi yang diberikan kepadanya tidak akan pernah berhasil.

Instruksi yang diberikan kepada anak autis, hanya berupa satu atau dua kata saja. Instruksi diberikan secara berulang-ulang sampai anak mau mengerjakan instruksi tersebut. Ibu Umi mengatakan,

"Saya memberi instruksi yang sangat sederhana dengan kalimat atau kata-kata sederhana seperti 'duduk bagus' dan diulang-ulang sampai mereka bisa melakukannya dengan benar" (Umi, Wawancara: 18 November 2016)

Jika anak tidak mau melakukan instruksi yang diberikan oleh guru, maka guru hanya perlu melakukan instruksi itu, dengan demikian anak akan melakukan imitasi. Karena pada dasarnya anak autis suka melakukan imitasi.

Objek garapkll;an selanjutnya dari anak yang mengalami keterlambatan bicara, adalah vocal, dasar bagi bahasa ekspresif, kemudian bertahap menjadi satu kata kemudian baru kalimat yang lebih panjang. Hal ini sesuai dengan apa yang diungkapkan oleh Ibu Umi,

"Untuk anak yang mengalami speaking delay, biasanya kami meminta mereka menirukan bunyi vocal dulu kemudian kalau sudah bisa dilanjutan dengan menirukan kata dan nantinya kalimat yang lebih panjang. Selain itu juga diberi terapi untuk oral motorik satu kali dalam seminggu." (Umi, Wawancara: 18 November 2016).

\section{Tahap Terapi Massage.}

Menurut Dr. Sulistiyawati Hoedijono, pemberian terapi pijat bagi anak autis, dapat mengoptimalkan kerja syaraf pada anak autis. Karena pada dasarnya autis dipandang sebagai gangguan perkembangan saraf dan kepekaan, Oleh karena itu, perlu terapi yang dapat mengoptimalisasi kerja system saraf otak, seperti pemijatan pada beberapa titik saraf tertentu (Hoedijono, 2016: - ). Selain terapi bicara, sekolah ini juga memberikan terapi pijat (massotherapy). Terapi pijat ini dilakukan oleh Pak Alfred, seminggu satu kali. Dalam terapi ini, anak diberikan terapi oral motorik dengan meniup balon, membersihkan lidah, dan memasukkan sebuah alat terapi ke mulut untuk mengaktifkan syaraf-syaraf yang berkaitan dengan kemampuan berbicara. Pemijatan juga dilakukan pada bagian leher untuk memperbaiki susunan syarat yang berkaitan dengan ketrampilan berbicara. Hal ini sesuai dengan hasil observasi peneliti dan hasil wawancara peneliti dengan Kepala Sekolah. Ibu Lilik mengatakan,

"Bersamaan dengan terapi bicara itu, juga dilakukan terapi pijat mbak, ada sebuah alat yang dimasukkan ke dalam mulut anak. Alat ini akan bergetar dan mengaktifkan syarafsyaraf yang berkaitan dengan kemampuan bicara atau berbahasa. Karena kalau tidak dibarengi dengan terapi message, terapi bicara juga tidak akan berhasil, seperti orang 
stroke itu katakanlah, mereka paham kalau mereka harus mengangkat tangan atau mengucapkan huruf ' $a$ ', tetapi tanpa bantuan dari terapis atau dibantu tangan yang satunya mengangkat tangannya sedikit demi sedikit, apa mereka bisa? Mereka paham tapi mereka tidak bisa melakukannya. Anak-anak juga begitu" (Lilik Sriyanti, Wawancara, 21 November 2016).

\section{Tahap Interaksi Teman Sebaya.}

Pada tahap ini anak diajarkan untuk berkomunikasi dengan teman sebaya pada saat istirahat. Pada saat istirahat anak digabugkan dengan beberapa anak dari kelas lain, dan pada saat pulang mereka harus berkunjung ke setiap kelas untuk berpamitan. Ibu Vina menjelaskan,

"Selama istirahat, anak-anak akan bercampur bersama di bawah pengawasan guru. Kami akan meminta mereka untuk menyapa dan bersalaman. Kalau hal-ha simpel ini diajarkan terus-menerus setiap hari, maka akan meningkatkan kemampuan sosial anak. (Vina, Wawancara, 18 November 2016)

Ibu Umi juga mengatakan hal yang sama, "Untuk murid tertentu yang sudah bisa berkomunikasi walaupun terbatas, biasanya kami ajak bermain dengan temannya di kelas yang lain... "(Umi, Wawancara, 18 November 2016).

J David Smith mengungkapkan, membaurkan anak dengan hambatan berbicara dengan teman yang memiliki pemahaman, kepekaan, dan mampu menjadi teladan yang baik merupakan salah satu penanganan kelas inklusif yang efektif (Smith, 2013: 216-217). Maka langkah yang dilakukan oleh guru-guru di Talenta Kids ini sudah benar, karena dengan interaksi teman sebaya yang memiliki pemahaman, akan dapat meningkatkan kepercayaan diri anak yang mengalami keterlambatan bicara, juga mendorong mereka untuk mampu berkomunikasi sebagaimana temannya.

\section{Tahap Interaksi dengan Lingkungan Sekolah}

Walaupun sekolah ini merupakan sekolah yang eksklusif namun kepala sekolah dan guru di sini sangat menyadari bahwa anak memiliki hak untuk dapat diterima di masyarakat sekitarnya. Maka dari itu, setiap hari Jumat anak diajak untuk berjalan-jalan mengelilingi lingkungan sekitar sekolah. Lingkungan sekitar berupa perumahan, dan terdapat sebuah desa di dekat perumahan tersebut. Dalam perjalanan mereka akan bertemu dengan beberapa orang pastinya, dengan profesi yang berbeda-beda. Hal inilah yang dimanfaatkan oleh guru untuk mengembangkan kemampuan komunikasi anak. Biasanya guru akan menyapa orang tersebut, dan terkadang anak-anak menanyakan banyak pertanyaan kepada mereka.

Waktu yang dibutuhkan oleh anak dari awal terapi sampai dengan anak mampu berkomunikasi dengan lingkungan sekitar berbeda-beda. Hal ini dipengaruhi oleh beberapa faktor, seperti kondisi anak yang berbeda, sikap proaktif anak, lamanya terapi, kerjasama orang tua, dukungan lingkungan sekitar anak, pola hidup dari sang anak sendiri. Begitulah yang diungkapkan oleh Ibu Lilik,

"Ya kalau keberhasilan terapi itu, setiap anak berbeda-beda mbak. Ada yang lama ada juga yang reatif cepat, kan semua itu dipengaruhi banya hal seperti kondisi anak sendiri, sifat proaktif dari anak juga berbeda, lama jadwal terapi, kerjasama orang tua. Kadang orang tua sudah diberi buku penghubung, tatapi mereka juga tidak merespon, kalau orang tuanya bisa diajak kerjasama pasti cepat ko mbak. Orang tua yang aktif itu, mereka memperhatikan buku penghubung, dan benar-benar menjaga diet anak."(Lilik Sriyanti, Wawancara, 21 November 2016)

Setelah anak berhasil untuk mengembangkan kemampuan berbahasanya biasanya, anak akan pindah ke sekolah umum atau ke sekolah inklusif, sebagaimana yang diungkapkan 
oleh Ibu Raras ketika peneliti bertanya apakah ada anak yang bisa sembuh dalam atian dapat berkomunikasi, Ibu Raras menjawab,

"Ada beberapa. Tetapi biasanya kalau sudah bisa dia dipindah ke sekolah biasa. Pada awalnya mereka juga tidak bisa bicara, hanya bergumam seperti anak kecil, kemudian kami beri gambar dan suruh mereka menirukan bunyi vokal, setelah itu dia bisa mengucapkan satu dua kata, sampai akhirnya anak dapat mengungkapkan apa yang dia inginkan. Walaupun terbatas bicaranya, tetapi itu sudah bagus, dan biasanya orang tua menginginkannya dipindah ke sekolah umum. "(Raras, Wawancara, 21 November 2016).

Terapi sosial yang dilakukan oleh Talenta Kids senada dengan tujuan terapi bagi anak autis menurut Widiastuti. Ia menyebutkan bahwa tujuan terapi bagi anak autis adalah untuk mengurangi masalah perilaku, meningkatkan kemampuan dan perkembangan belajar anak dalam hal penguasaan bahasa dan membantu anak autis agar mampu bersosialisasi dan beradaptasi dengan lingkungan sosialnya (Widhiastuti, 2007: 13). Lebih jauh ia menyebutkan bahwa tujuan pendidikan bagi anak autis adalah untuk mengeliminasi perbedaan dengan cara menekan gejala-gejala yang dialami oleh anak autis menjadi tidak kentara lagi ketika bergaul di lingkungan sekitar. Maka dengan membaurkan anak dengan lingkungan sekitar sama saja dengan melatih anak untuk terbiasa bergaul dengan dunia sekitar. Hal ini juga dapat menekan gejala-gejala yang dialami oleh anak autis agar tidak teralalu kentara terlihat berbeda dengan lingkungan sekitarnya (Widhiastuti, 2007: 14).

\section{KESIMPULAN}

Berdasarkan uraian di atas, maka dapat disimpulkan bahwa Sekolah Autis Talenta Kids merupakan sekolah eksklusif yang menggunakan prinsip-prinsip sekolah inklusif. Talenta Kids menggunakan kurikulum nasional yang dimodifikasi sedemikian rupa sehingga dapat memenuhi kebutuhan anak. Begitu juga sekolah ini masih memahami pentingnya interkasi dan komunikasi bagi anak autis, ssehingga guru sering mengajak anak untuk berinteraksi dengan teman sebaya dari kelas lain, dan berinteraksi dengan masyarakat di sekitar lingkungan sekolah.

Berkaitan dengan pemerolehan bahasa anak autis sendiri, Talenta Kids lebih menggunakan mengacu pada prinsip learning theory, dimana pemerolehan bahasa ibu bagi anak autis harus melalui proses pengajaran atau pemberian contoh-contoh bunyi dari orangorang yang tinggal di lingkungan sekitar seperti teman, guru, orang tua dan masyarakat di lingkungan tempat tinggal anak. Pemerolehan bahasa AUD autis di Talenta Kids melalui lima langkah yang pasti dilewati oleh guru yang mengaja anak dengan keterlambatan bicara atau gangguan bicara. Langkah-langkah tersebut antara lain; 1) Identifikasi kebutuhan anak yang dilakukan ketika anak mendaftar ke Sekolah Autis Talenta Kids, baik melalui observasi kepada anak, wawancara orang tua, atau dengan mempelajari rekam medis atau catatatn terapi sang anak. 2) Terapi bicara, yang dilakukan oleh paraprofesional dan juga dilakukan oleh guru-guru sendiri. Konsep inilah yang menunjukkan sifat inklusif dari sekolah dimana guru kelas juga menguasai terapi yang harus diberikan kepada anak. Guru kelas tdak hanya meberikan materi tetapi juga memberikan terapi. 3) Terapi message, yang dilakuakn oleh terapis juga untuk membantu mengaktifkan syaraf-syaraf yang berkaitan dengan produksi suara anak. 4) Interaksi dengan teman sebaya, yang dilakukan setiap istirahat dan ketika jam pulang sekolah yang dapat merangsang anak untuk mempunyai keinginan untuk dapat berbicara seperti temannya. 5) Interaksi dengan lingkungan sekitar sekolah, yang dilakukan setiap hari Jumat. Langkah terkahir ini bertujuan agar anak autis juga dapat berbaur dengan masyarakat sekitar, karena autis juga bagian dari masyarakat itu sendiri. 


\section{DAFTAR PUSTAKA}

Azwandi, Yosfan. 2005. Mengenal dan Membantu Penyandang Autisme, (Jakarta: Departemen Pendidikan Nasional.

Chaer, Abdul. 2009. Psikolinguistik Kajian Teoritik, Jakarta: Rineka Cipta.

Ellen, Braten dan Felopolus Gretchen, 2004. Straight Talk about Psychological Testing For Kids. New York: Guilford,

Emzir, 2011. Metodologi Penelitian Kualitatif: Analisis Data. Cetakan Ke-2. Jakarta Utara: PT Rajagrafindo Persada.

Ezmar dan Ramli, "Bahasa Anak Autis pada SLB Cinta Mandiri Lhoksumawe" Metamorfosa Volume II Nomor 2 Juli-Desember 2014, hlm. 1-18.

Fadli, Syukron Ro'al dan Ma'rifatun Nisa, 2014. Perbedaan Pemerolehan Bahasa dan Pembelajaran Bahasa. Yogyakarta: UIN SUKA.

Handojo, 2008. Autisme pada Anak. Jakarta: PT Bhuana Ilmu Populer.

Hoedijono, Sulistiyawati. 2016. Alternatif Penyembuhan Anka Autis: Berikan Sentuhan Acupressure, Perhatikan Diet Glutein dan Kasein. fk.unair.ac.id diakses tanggal 19 Desember 2016.

Ilahi, Mohammad Takdir. 2013. Pendidikan Inklusif: Konsep dan Aplikasi, Yogyakarta, ArRuzz Media.

Moleong, Lexy J. 2012. Metodologi Penelitian Kualitatif. Bandung: PT Remaja Rosdakarya. Pamuji, 2007. Model Terapi Terpadu bagi Anak Autsme, Jakarta: Departemen Pendidikan Nasional.

Robertson K., Chamberlain B., \& Kasari C., “General Education Teachers' Relationship with Included students with autism. Journal of Autism and Developmental Disorder, 33(2) 2003 hlm. 123-130.

Santrock, John W. 2007.Child Development, Eleventh Edition, terj- Mila Rachmawati dan Anna Kuswanti, Perkembangan Anak, Jakarta: Erlangga.

Sastry, Anjali \& Blaise Aguirre, 2014. Parenting Your Child with Autism: Practical Solutions, Strateges and Advice for Helping Your Family, terj- Yudi Santoso, Parenting Anak dengan Autisme: Solusi, Strateg, dan Saran Praktis untuk Membantu Keluarga Anda, Yogyakarta: Pustaka Pelajar.

Smith, J. David. 2013. Inclusion, School for All Student, terj. Denis Ny. Enrica, Sekolah Inklusif: Konsep dan Penerapan Pembelajaran Cetakan V, Bandung: Nuansa Cendekia.

Sugiyono, 2010. Metode Penelitian Pendidikan: Pendekatan Kuantitatif, Kualitatif dan $R \& D$. Bandung: Alfabeta,

Suhartono, 2005. Pengembangan Ketrampilan Bicara Anak Usia Dini, Jakarta: Departemen Pendidikan Nasional.

Widhiastuti, Setiati. 2007. Pola Pendidikan Anak Autis. Yogyakarta: CV Datamedia. 